\title{
PERAN PEJABAT PEMBUAT AKTA TANAH DALAM MEMINIMALISIR SENGKETA TANAH
}

\author{
Mulia Kartiwi \\ Sekolah Tinggi Hukum Garut \\ muliakartiwi@gmail.com
}

\begin{abstract}
Until this day land disputes in Indonesia still occur, although goverment has issued regulation for land registration that aims to create legal certainty for occupied land subject and object. This study is a descriptive analysis wish normative juridical approach that aims to find out and analyze the causal factor the land disputes and to determince the role of PPAT in minimizing land disputes. Result showed that the causal factor of land dispute is the unavailability of authentic certificate that prove the ownership of the land right, so that they are easily intervened. Futhermore, the role of PPAT is very important in land registration because the product can be used as basis for issuance of land certificate as a strong evidence. For that reason PPAT must carry out its duties with cautious and professional to avoid mistake that can cause losses
\end{abstract}

Keywords : Role, PPAT, Minimizing, Land Dispute

Abstrak

Saat ini sengketa tanah di Indonesia masih terjadi, walaupun pemerintah telah menerbitkan aturan tentang pendaftaran tanah yang bertujuan menciptakan kepastian hukum akan subjek dan objek tanah yang dikuasai.Penelitian ini bersifat deskriptif analisis dengan metode pendekatan yuridis normatif yangbertujuan untuk mengetahui dan menganalisa faktor-faktor penyebab sengketa tanah dan mengetahui peran PPAT dalam meminimalisir sengketa tanah. Dari hasil penelitian dapat disimpulkan bahwa penyebab sengketa pertanahan diantaranya ketidaktersediaan akta otentik yang membuktikan kepemilikan hak tanah, sehingga mudah diintervensi oleh pihak lain. Selanjutnya Peran PPAT sangat penting dalam pendaftaran tanah, karena produknya dijadikan dasar untuk penerbitan sertifikat tanah sebagai alat bukti yang kuat.Untuk itu PPAT dalam melaksanakan tugasnya agar berhati-hati dan professional guna menghindari kekeliruan yang dapat menyebabkan kerugian.

Kata Kunci : Peran, PPAT, Meminimalisir, Sengketa Tanah.

\section{PENDAHULUAN}

Tanah adalah sumber daya alam yang sangat penting bagi kehidupan manusia,oleh karena itu Pasal 33 ayat (3) Undang-Undang Dasar 1945 mengatur bumi dan air dan kekayaan alam yang terkandung di dalamnya dikuasai oleh negara dan dipergunakan untuk sebesar-besar kemakmuran rakyat. Sumber daya tanah dan sumber daya alam lainnya bukanlah milik satu golongan tertentu, namun kepunyaan kita semua sebagai bangsa. Kepada negara sebagai organisasi kekuasaan tertinggi dari seluruh bangsa dibebankan amanah untuk mengatur penggunaan tanah bagi kemakmuran seluruh komponen bangsa dan bukan kelompok tertentu. (Nurhasan Ismail, $2011: 2$ )

Amanah tersebut dijabarkan dalam Pasal 2 ayat (2) Undang-Undang Nomor 5 Tahun 1960 tentang Peraturan Dasar Pokok-Pokok Agraria bahwa hak menguasai dari Negara memberi wewenang untuk : 
a. Mengatur dan menyelenggarakan peruntukan, penggunaan, persediaan dan pemeliharaan bumi, air dan ruang angkasa tersebut;

b. Menentukan dan mengatur hubungan-hubungan hukum antara orang-orang dengan bumi, air dan ruang angkasa;

c. Menentukan dan mengatur hubungan-hubungan hukum antara orang-orang dan perbuatan-perbuatan hukum yang mengenai, buni,air dan ruang angkasa.

Jumlah penduduk yang terus meningkat serta aktivitas pembangunan di berbagai sektor, semua subjek hukum baik manusia maupun badan hukum publik dan swasta memerlukan tanah untuk memenuhi kebutuhannya, sementara ketersediaan tanah yang terbatas tentunya dapat menimbulkan konflik /sengketa di bidang pertanahan.

Menurut Sihombing (2005:2) secara historis puncak sengketa pertanahan sebenarnya telah terjadi sejak diberlakukannya Agrarische Wet pada tahun 1870, di mana sumber utama konflik adalah ketidakharmonisan, ketidakselarasan atau ketimpangan dalam struktur kepemilikan dan penguasaan tanah.

Untuk mencegah terjadinya sengketa tanah, pemerintah telah menerbitkan Peraturan Pemerintah Nomor 10 tahun 1961 tentang Pendaftaran Tanah, namun perkembangan masyarakat yang begitu cepat dan banyaknya persoalan pendaftaran tanah yang muncul dan tidak mampu diselesaikan maka, setelah berlaku selama 38 tahun, pemerintah mengeluarkan Peraturan Pemerintah Nomor 24 tahun 1997 tentang Pendaftaran Tanah bertujuan menjamin kepastian akan subjek dan objek penguasaan tanah, tertib administrasi pertanahan serta memberikan informasi kepada pihak lain akan penguasaan tanah tersebut, dengan diterbitkannya sebuah sertifikat sebagai alat bukti kepemilikan yang kuat. Untuk penerbitan sertifikat oleh badan Pertanahan disyaratkan adanya alas hak atas tanah tersebut yang dibuktikan dengan sebuah akta yang dibuat di hadapan Pejabat Pembuat Akta Tanah (PPAT).

Berdasarkan latar belakang tersebut dapat diidentifikasi masalah berikut faktor-faktor apa saja yang menyebabkan terjadinya sengketa pertanahan tetap terjadi dan bagaimana peran PPAT dalam meminimalisir sengketa pertanahan?.

\section{METODE PENELITIAN}

Metode penelitian yang digunakan bersifat deskriptif analisis yaitu menggambarkan permasalahan-permsalahan yang terjadi kemudian dianalisis dengan metode pendekatan yuridis normative. Menurut Ronny (Hanitijo 1998:11) penelitian hukum normatif merupakan penelitian kepustakaan terhadap data sekunder. Penelitian ini dapat dilakukan terhadap bahan hukum primer dan bahan hukum sekunder, yaitu apabila bahan-bahan tadi mengandung norma-norma hukum. Data-data yang diperoleh selanjutnya diolah dan dianalisis secara kualitatif, dengan menggunakan metode berfikir deduktif, di mana data yang telah terkumpul diolah secara selektif dan sistematis dan kemudian ditarik kesimpulan akhir yang bersifat khusus, yaitu merupakan kristalisasi dari hasil analisis data dari penelitian, tanpa menggunakan rumusan statistik.

(Soerjono

Soekanto dan Sri Mamudji , 1995 : 31)

\section{PEMBAHASAN}

Pendaftaran tanah merupakan persoalan yang sangat penting, karena pendaftaran tanah merupakan awal dari proses lahirnya sebuah bukti kepemilikan ha katas tanah. Begitu pentingnya masalah pendaftaran tanah Undang- Undang nomor 5 tahun 1960 
tentang Peraturan Dasar Pokok-Pokok Agraria yang lebih dikenal dengan UUPA, mengamanatkan kepada Pemerintah untuk melakukan pendaftaran tanah di seluruh wilayah Indonesia, seperti tercantum dalam Pasal 19 ayat (1) UUPA Nomor 5 Tahun 1960 menyebutkan bahwa:

1. Untuk menjamin kepastian hukum oleh Pemerintah diadakan pendaftaran tanah di seluruh wilayah Republik Indonesia menurut ketentuan-ketentuan yang diatur dengan Peraturan Pemerintah.

2. Pendaftaran tanah tersebut meliputi:

a. Pengukuran, perpetaan dan pembukuan tanah;

b. Pendaftaran hak atas tanah dan peralihan hak-hak tersebut;

c. Pemberian surat-surat tanda bukti hak, yang berlaku sebagai alat pembuktian yang kuat.

3. Pendaftaran diselenggarakan dengan mengingat keadaan negara dan masyarakat, keperluan lalulintas sosial ekonomi serta kemungkinan penyelenggaraannya menurut pertimbangan Menteri Agraria.

4. Dalam Peraturan Pemerintah diatur biaya-biaya yang bersangkutan dengan dengan pendaftaran dengan ketentuan bahwa raktyat yang tidak mampu dibebaskan dari biaya-biaya tersebut.

Pasal tersebut tidak memberikan pengertian atau batasan tentang pendaftaran tanah yang jelas. Oleh karena itu diberikan pengertian yang jelas tentang pendaftran tanah dalam Pasal 1 angka 1 Peraturan Pemerintah Nomor 24 tahun 1997 tentang Pendaftaran Tanah, yang menjelaskan bahwa pendaftaran tanah adalah rangkaian kegiatan yang dilakukan oleh pemerintah secara terus menerus, berkesinambungan dan teratur, yang meliputi pengumpulan, pengolahan, pembukuan, dan penyajian serta pemeliharaan data fisik dan data yuridis, dalam bentuk peta dan daftar, mengenai bidang-bidang tanah dan satuan-satuan rumah susun, termasuk pemberian surat tanda bukti haknya bagi bidang-bidang tanah yang sudah ada haknya dan hak milik atas satuan rumah susun serta hak-hak tertentu yang membebaninya.

Kemudian disimpulkan oleh Boedi Harsono (2003:72) yang menyebutkan bahwa pendaftaran tanah adalah rangkaian kegiatan yang dilakukan oleh Negara/pemerintah secara terus menerus dan teratur berupa pengumpulan keterangan atau data tertentu yang ada di wilayah-wilayah tertentu, pengelolaan, penyimpanan dan penyajiannya bagi kepentingan rakyat dalam rangka memberikan jaminan kepastian hukum di bidang pertanahan, termasuk penerbitan tanda buktinya dan pemeliharannya.

Selanjutnya Pasal 1 angka 20 Peraturan Pemerintah Nomor 24 tahun 1997 tentang Pendaftaran Tanah menyebutkan bahwa sertifikat adalah surat tanda bukti hak yang berlaku sebagai alat pembuktian yang kuat untuk hak atas tanah, hak pengelolaan, tanah wakaf, hak milik atas satuan rumah susun dan hak tanggungan yang masing-masing sudah dibukukan dalam buku tanah yang bersangkutan.

Pasal 32 ayat (1) Peraturan Pemerintah Nomor 24 tahun 1997 tentang Pendaftaran Tanah menyebutkan bahwa sertifikat merupakan surat tanda bukti hak yang berlaku sebagai alat pembuktian yang kuat mengenai data fisik dan data yuridis yang termuat di dalamnya, sepanjang data fisik dan data yuridis tersebut sesuai dengan data yang ada dalam surat ukur dan buku tanah hak yang bersangkutan. 
Pendaftaran tanah mempunyai manfaat bagi pemegang hak atas tanah antara lain mencegah intervensi pihak lain; tanah-tanah yang bersertifikat akan bernilai tinggi dan dapat dijadikan tanggungan dalam perjanjian utang piutang.

Adapun tanah-tanah yang harus didaftarkan berdasarkan Pasal 9 ayat (1) Peraturan Pemerintah Nomor 24 tahun 1997 tentang Pendaftaran Tanah,adalah:

1. Bidang-bidang tanah yang dipunyai dengan hak milik, hak guna usaha, hak guna bangunan dan hak pakai;

2. Tanah hak pengelolaan;

3. Tanah wakaf;

4. Hak milik atas satuan rumah susun;

5. Hak tanggungan;

6. Tanah Negara.

Menurut Waskito (2017: 175) salah satu unsur yang penting dalam administrasi pertanahan adalah Pejabat Pembuat Akta Tanah (PPAT). Istilah PPAT disebutkan dalam Peraturan Pemerintah Nomor 24 tahun 1997 tentang Pendaftaran Tanah yang memiliki peran membuat akta untuk peralihan hak atas tanah. Akta yang dibuat PPAT tersebut merupakan persyaratan agar tanah dapat didaftar. Demikian pula menurut Supriadi (2006 : 168) Keberadaan pejabat dalam suatu ketatanegaraan sangat dibutuhkan, karena pejabat merupakan pengejawantahan dari personifikasi Negara. Negara dalam konsep ketatanegaraan dalam menjalankan fungsinya diwakili oleh pemerintah, pemerintah dalam menjalankan fungsi dan tugasnya dalam merealisasikan tujuan Negara diwakili oleh pejabat.

Pasal 1 angka 24 Peraturan Pemerintah Nomor 24 Tahun 1997 Tentang Pendaftaran Tanah, bahwa "Pejabat Pembuat Akta Tanah, selanjutnya disebut PPAT adalah pejabat umum yang diberi kewenangan untuk membuat akta-akta tanah tertentu".

Pasal 37 ayat (1) Peraturan Pemerintah Nomor 24 tahun 1997 tentang Pendaftaran Tanah menyebutkan bahwa: "Peralihan hak atas tanah dan hak milik atas satuan rumah susun melalui jual beli, tukar menukar, hibah, pemasukan dalam perusahaan dan perbuatan hukum pemindahan hak lainnya, kecuali pemindahan hak melalui lelang, hanya dapat didaftarkan, jika dibuktikan dengan akta yang dibuat oleh PPAT yang berwenang menurut ketentuan peraturan perundang-undangan yang berlaku".

Menurut Boedi Harsono (2003: 486) yang dimaksud dengan "pejabat umum" itu adalah orang yang diangkat oleh Instansi yang berwenang, dengan tugas melayani masyarakat umum di bidang atau kegiatan tertentu.

Pasal 1 Peraturan Pemerintah Nomor 24 Tahun 2016 Tentang Perubahan Atas Peraturan Pemerintah Nomor 37 Tahun 1998 Tentang Peraturan PPAT, membedakan Pejabat Pembuat Akta Tanah menjadi 3 (tiga) macam, yaitu :

1. Pejabat Pembuat Akta Tanah

Adalah pejabat umum yang diberikan kewenangan untuk membuat akta-akta otentik mengenai perbuatan hukum tertentu mengenai hak atas tanah atau Hak Milik Atas Satuan Rumah Susun.

2. Pejabat Pembuat Akta Tanah Sementara

Adalah pejabat Pemerintah yang ditunjuk karena jabatannya untuk melaksanakan tugas PPAT dengan membuat akta PPAT di daerah yang belum cukup terdapat PPAT.

3. Pejabat Pembuat Akta Tanah Khusus (PPAT Khusus). 


\section{Res Nullius}

Law Journal

Vol. 2 No. 1 Januari 2020

PPAT Khusus adalah pejabat Badan Pertanahan Nasional yang ditunjuk karena jabatannya untuk melaksanakan tugas PPAT dengan membuat akta PPAT tertentu khusus dalam rangka pelaksanaan program atau tugas Pemerintah tertentu.

Untuk diangkat menjadi Pejabat Pembuat Akta Tanah harus memenuhi persyaratan sebagai berikut :

a. Warga Negara Indonesia

b. Berusia paling rendah 22 (dua puluh dua ) tahun.

c. Berkelakuan baik yang dinyatakan dengan surat keterangan yang dibuat oleh instansi kepolisian.

d. Tidak pernah dijatuhi pidana penjara berdasarkan putusan pengadilan yang telah memperoleh kekuatan hukum tetap karena melakukan tindak pidana yang diancam dengan pidana penjara 5 (lima) tahun atau lebih.

e. Sehat jasmani dan rohani.

f. Berijazah Sarjana Hukum dan lulusan jenjang strata dua kenotariatan atau lulusan program pendidikan khusus PPAT yang diselenggarakan oleh kementrian yang menyelenggarakan urusan di bidang agraria/pertanahan.

g. Lulus ujian yang diselenggarakan oleh kementrian yang menyelenggarakan urusan pemerintahan di bidang agrarian/pertanahan.

h. Telah menjalani magang atau nyata-nyata telah bekerja sebagai karyawan pada kantor PPAT paling sedikit 1 (satu) tahun setelah lulus pendidikan kenotariatan.

Larangan untuk PPAT diatur dalam Pasal 7 ayat (2) Peraturan Pemerintah Nomor 24 Tahun 2016 Tentang Peraturan Jabatan PPAT yaitu :

PPAT dilarang merangkap jabatan atau profesi:

a. advokat, konsultan atau penasehat hukum;

b. pegawai negeri, pegawai badan usaha milik negara, pegawai badan usaha milik daerah pegawai swasta;

a. pejabat negara atau Pegawai Pemerintah dengan Perjanian Kerja (PPPK) ;

b. pimpinan pada sekolah, perguruan tinggi negeri,atau perguruan tinggi swasta;

c. surveyor berlisensi;

d. penilai tanah;

e. mediator; dan/atau jabatan lainnya yang dilarang oleh peraturan perundangundangan.

\section{Faktor-Faktor Penye bab Sengke ta Pertanahan}

Menurut Pasal 1 Peraturan Menteri Agraria dan Tata Ruang / Badan Pertanahan Nasional Nomor 11 Tahun 2016 tentang Penyelesaian Kasus Pertanahan bahwa yang dimaksud dengan sengketa tanah adalah perselisihan pertanahan antara orang perseorangan, badan hukum, atau lembaga yang tidak berdampak luas. Sedangkan konflik tanah adalah perselisihan pertanahan antara orang perseorangan, kelompok, golongan, organisasi, badan hukum, atau lembaga yang mempunyai kecenderungan atau sudah berdampak luas.

Menurut Darwin Ginting (2010: 2 ) Sengketa pertanahan adalah perselisihan yang terjadi antara dua pihak atau lebih yang merasa atau dirugikan pihak-pihak tersebut untuk penggunaan dan penguasaan hak atas tanahnya yang diselesaikan melalui musyawarah atau pengadilan. Menurutnya bahwa akar permasalahan sengketa pertanahan secara komprehensif disebabkan oleh: 
1. Kurang tertibnya administrasi petanahan masa lalu.

2. Ketimpangan struktur penguasaan dan pemilikan tanah

3. Meningkatnya kebutuhan tanah sehingga harga tanah, sehingga harga tanah tidak dapat dikendalikan karena ulah mafia tanah.

4. Sistem publikasi pendaftaran tanah negatif

5. Tumpang tindihnya peraturan perundangan tentang tanah

6. Masih banyaknya terdapat tanah terlantar

7. Kurang cermatnya notaris dan PPAT dalam menjalankan tugasnya.

8. Belum terdapat persamaan presepsi atau interpretasi para penegak hukum khususnya hakim terhadap peraturan perundang-undangan di bidang pertanahan.

9. Para penegak hukum belum mempunyai komitmen untuk melaksanakan peraturan perundang-undangan secara konsekuen dan konsisten.

Menurut Siswanto (2011: 3 ) anatomi sengketa pertanahan dapat dilihat dari :

1. Tipologi Sengketa Pertanahan

a. Masalah konversi tanah bekas hak Barat

b. Masalah penguasaan dan pemilikan tanah

c. Masalah tumpang tindih ijin lokasi

d. Masalah batas dan letak bidang tanah

e. Masalah ganti rugi tanah eks tanah partikelir

f. Sengketa tanah obyek landreform

g. Sengketa tanah ulayat

h. Sengketa putusan pengadilan

i. Sengketa pengadaan tanah

2. Substansi sengketa pertanahan meliputi:

a. Peruntukan dan/atau penggunaan serta penguasaan hak atas tanah

b. Keabsahan suatu hak aas tanah

c. Prosedur pemberian hak atas tanah

d. Pendaftaran hak atas tanah termasuk peralihan dan penerbitan serifikat sebagai tanda bukti hak.

3. Pihak-pihak yang bersengketa

a. Perorangan melawan perorangan

b. Perorangan melawan Badan hukum

c. Perorangan melawan Instasni Pemerintah

d. Badan Hukum melawan Badan Hukum

e. Badan Hukum melawan Instansi Pemerintah

f. Badan Hukum melawan masyarakat

g. Instansi Pemerintah melawan instansi Pemerintah

h. Instansi Pemerintah melawan Masyarakat

Permasalahan Sengketa tanah di Indonesia masih sering terjadi. Menurut Kabag Humas Kementerian ATR/BPN, Harison Mocodompis, sepanjang tahun 2018 tercatat ada 2.546 sengketa tanah.Sengketa konflik yang sudah selesai ditangani sejumlah 1.652 kasus. Selanjutnya menurut Dirjen Penanganan Masalah Agraria, Pemanfaatan Ruang dan Tanah, Agus Widjayanto , sengketa yang terjadi karena beragamnya masalah yang menjadi dasar dalam pembuatan sertifikat. (Harian Kompas Rabu, 27/2/2019). 


\section{DN Tes Nullius}

Law Journal

Vol. 2 No. 1 Januari 2020

Tabel 1. STATISTIK PERKARA PERDATA KLASIFIKASI OBJEK SENGKETA TANAH TAHUN 2018 ( Mahkamah Agung Republik Indonesia )

\begin{tabular}{|c|c|c|c|c|c|c|}
\hline No & Jenis Perkara & Sisa & Masuk & Beban & Cabut & Putus \\
\hline 1 & $\begin{array}{l}\text { Objek Sengketa } \\
\text { Tanah/Wanprestasi/Jual Beli } \\
\text { Tanah }\end{array}$ & 106 & 255 & 361 & 18 & 248 \\
\hline 2 & $\begin{array}{l}\text { Objek Sengketa } \\
\text { Tanah/Perbuatan Melawan } \\
\text { Hukum/Hak } \\
\text { Ulayat/Persekutuan Adat }\end{array}$ & 2 & 5 & 7 & 0 & 6 \\
\hline 3 & $\begin{array}{l}\text { Objek Sengketa } \\
\text { Tanah/Perbuatan Melawan } \\
\text { Hukum/Penyalahgunaan Hak }\end{array}$ & 9 & 29 & 38 & 3 & 24 \\
\hline 4 & Objek Sengketa Tanah & 909 & 1861 & 2770 & 173 & 1819 \\
\hline 5 & $\begin{array}{l}\text { Objek Sengketa } \\
\text { Tanah/Wanprestasi } \\
\text { Objek Sengketa }\end{array}$ & 440 & 1081 & 1521 & 90 & 956 \\
\hline 6 & $\begin{array}{l}\text { Tanah/Perbuatan Melawan } \\
\text { Hukum }\end{array}$ & 2933 & 6225 & 9158 & 531 & 5907 \\
\hline 7 & $\begin{array}{l}\text { Objek Sengketa } \\
\text { Tanah/Wanprestasi/Hibah } \\
\text { Objek Sengketa }\end{array}$ & 5 & 12 & 17 & 0 & 13 \\
\hline 8 & $\begin{array}{l}\text { Tanah/Wanprestasi/Sewa } \\
\text { Menyewa }\end{array}$ & 5 & 8 & 13 & 3 & 10 \\
\hline 9 & $\begin{array}{l}\text { Objek Sengketa } \\
\text { Tanah/Wanprestasi/Jual Gadai } \\
\text { Objek Sengketa }\end{array}$ & 0 & 9 & 9 & 0 & 5 \\
\hline & $\begin{array}{l}\text { Tanah/Wanprestasi/Harta } \\
\text { Bersama }\end{array}$ & 24 & 76 & 100 & 8 & 70 \\
\hline 11 & $\begin{array}{l}\text { Objek Sengketa } \\
\text { Tanah/Wanprestasi/Ganti Rugi }\end{array}$ & 31 & 78 & 109 & 6 & 66 \\
\hline & $\begin{array}{l}\text { Objek Sengketa } \\
\text { Tanah/Perbuatan Melawan } \\
\text { Hukum/Penyerobotan }\end{array}$ & 18 & 33 & 51 & 2 & 37 \\
\hline 13 & $\begin{array}{l}\text { Objek Sengketa } \\
\text { Tanah/Perbuatan Melawan } \\
\text { Hukum/Pusaka Tinggi/Pusaka } \\
\text { Rendah }\end{array}$ & 32 & 65 & 97 & 4 & 67 \\
\hline & $\begin{array}{l}\text { Objek Sengketa } \\
\text { Tanah/Perbuatan Melawan } \\
\text { Hukum/Sertifikat/Girik }\end{array}$ & 44 & 100 & 144 & 7 & 108 \\
\hline & Objek Sengketa & 3 & 11 & 14 & 2 & $\begin{array}{l}10 \\
41\end{array}$ \\
\hline
\end{tabular}




\section{Res Nullius}

Law Journal

Vol. 2 No. 1 Januari 2020

Tanah/Perbuatan Melawan

Hukum/PPAT

Objek Sengketa

16 Tanah/Perbuatan Melawan Hukum/Ganti Rugi

Sumber: https://badilummahkamahagung .go.id diakses tanggal, 29 Desember 2019, pukul $\underline{19.30 .}$

Berdasarkan data-data tersebut sengketa pertanahan di negara kita masih sering terjadi, sehingga perlu diminimalisir.

\section{Peran Pejabat Pembuat Akta Tanah Dalam Meminimalisir Sengketa Tanah}

Masalah tanah selalu bersifat multiaspek dan multi kompleks, sehingga memerlukan pengaturan

dan penataan yang baik dan mendasar guna mengeliminasi, setidaknya meminimalisasi konflik berkaitan dengan tanah. Yunus Wahid (2014 : 201 ).

Hubungan hukum antara subjek hukum dengan tanah secara yuridis dibuktikan dengan keberadaan sertifikat yang diterbitkan oleh badan Pertanahan yang didasarkan pada akta yang dibuat oleh PPAT.

Pasal 2 Peraturan Pemerintah Republik Indonesia Nomor 37 Tahun 1998 Tentang Peraturan Jabatan Pejabat Pembuat Akta Tanah, memuat tugas pokok dan kewenangan PPAT yaitu :

1. PPAT bertugas pokok melaksanakan sebagian kegiatan pendaftaran tanah dengan membuat akta sebagai bukti telah dilakukannya perbuatan hukum tertentu mengenai hak atas tanah atau Hak Milik Atas Satuan Rumah Susun, yang akan dijadikan dasar bagi pendaftaran perubahan data pendaftaran tanah yang diakibatkan oleh perbuatan hukum itu.

2. Perbuatan hukum sebagaimana dimaksud pada ayat (1) adalah sebagai berikut:
a. Jual beli;
b. Tukar menukar;
c. Hibah;
d. Pemasukan ke dalam perusahaan (inbreng);
e. Pembagian hak bersama;
f. Pemberian Hak Guna Bangunan/Hak Pakai atas tanah Hak Milik;
g. Pemberian Hak Tanggungan;
h. Pemberian kuasa membebankan Hak Tanggungan.

Selanjutnya dalam Pasal 3 Peraturan Pemerintah tersebut diatur bahwa :

(1) Untuk melaksanakan tugas pokok sebagaimana dimaksud dalam Pasal 2 seorang PPAT mempunyai kewenangan membuat akta otentik mengenai semua perbuatan hukum sebagaimana dimaksud dalam Pasal 2 ayat (2) mengenai hak atas tanah dan Hak Milik Atas Satuan Rumah Susun yang terletak di dalam daerah kerjanya.

(2) PPAT khusus hanya berwenang membuat akta mengenai perbuatan hukum yang disebut secara khusus dalam penunjukannya.

Pasal 165 HIR menyebutkan yang dimaksud dengan akta otentik, yaitu suatu surat yang diperbuat oleh atau di hadapan pegawai umum yang berkuasa untuk membuatnya mewujudkan bukti yang cukup bagi kedua belah pihak dan ahli warisnya serta sekalian orang yang mendapat hak dari padanya yaitu tentang segala hal yang tersebut di dalam surat itu dan juga tentang yang tercantum dalam surat itu sebagai pemberitahuan sahaja, 
tetapi yang tersebut kemudian itu hanya jika yang diberitahukan itu langsung berhubungan dengan pokok dalam akta itu"

Pasal 1868 Kitab Undang-Undang Hukum Perdata menyebutkan bahwa suatu akta otentik ialah akta yang dibuat dalam bentuk yang ditentukan undang-undang oleh atau dihadapan pejabat umum yang berwenang untuk itu di tempat akta dibuat.

Dari penjelasan pasal tersebut akta otentik dibuat oleh atau dihadapan pejabat yang berwenang yang disebut pejabat umum. Apabila yang membuatnya pejabat yang tidak cakap atau tidak berwenang atau bentuknya cacat, maka menurut Pasal $1869 \mathrm{KUH}$ Perdata akta tersebut tidak sah, namun akta yang demikian mempunyai nilai kekuatan sebagai akta di bawah tangan dengan syarat apabila akta itu ditandatangani para pihak.( Yahya Harahap, 2014 : 566 ).

Abdul Manan (2000 : 139 ) menyebutkan bahwa akta otentik mempunyai tiga macam kekuatan pembuktian yaitu :

a. Pembuktian formal, yaitu pembuktikan antara para pihak bahwa mereka sudah menerangkan apa yang ditulis dalam akta tersebut.

b. Pembuktian materiil, yaitu pembuktikan antara para pihak, bahwa benar-benar peristiwa yang tersebut dalam akta itu telah terjadi.

c. Pembuktian mengikat, yaitu pembuktikan antara para pihak dan pihak ketiga, bahwa pada tanggal tersebut dalam akta yang bersangkutan telah datang menghadap kepada pegawai umum dan menerangkan apa yang ditulis dalam akta tersebut.

Pasal 164 HIR menempatkan alat bukti surat atau akta pada posisi pertama, selanjutnya saksi, pengakuan, persangkaan dan sumpah, karena alat bukti yang paling sempurna dalam hukum acara perdata adalah bukti tulis. Dalam lalulintas hukum perdata akta sengaja dibuat untuk alat bukti.

Betapa pentingnya peran PPAT dalam meminimalisir sengketa tanah, karena keberadaan akta yang dibuat oleh PPAT akan menjadikan dasar untuk penerbitan sertifikat sebagai bukti kepemilikan yang kuat, dan wajib diterima kebenarannya oleh hakim dalam persidangan sebagai alat bukti yang sempurna, jika terjadi gugatan di pengadilan.

PPAT sebagai pejabat umum yang berwenang membuat akta pemindahan hak atas tanah, pembebanan hak atas tanah, dan akta-akta lain yang diatur dengan peraturan perundang-undangan yang berlaku dan membantu Kepala Kantor Pertanahan dalam melaksanakan pendaftaran tanah tentunya harus mengedepankan prinsip profesionalisme dan prinsip kehati-hatian, agar akta yang dibuatnya bernilai untuk pembuktian di masa yang akan datang. Para pihak sengaja menggunakan jasa PPAT dalam melakukan sebuah perbuatan hukum agar mendapatkan kepastian dan perlindungan hukum apabila di kemudian hari terjadi peristiwa sengketa.

Profesionalisme merupakan persyaratan yang diperlukan untuk menjabat suatu pekerjaan (profesi) tertentu, yang melaksanakannya memerlukan ilmu pengetahuan, keterampilan, wawasan dan sikap yang mendukung sehingga pekerjaan profesi tersebut dapat dilaksanakan dengan baik. Dengan demikian dapat difahami bahwa profesionalisme merupakan suatu kualitas pribadi yang wajib dimiliki oleh seseorang dalam menjalankan suatu pekerjaan tertentu dalam melaksanakan pekerjaan yang diserahkan kepadanya.( Abdul Manan, 2007 : 194 )

Sedangkan yang dimaksud dengan azas kehati-hatian atau bertindak cermat meunurut Makhfudz (2013 : 45) bahwa setiap pejabat administrasi Negara harus bertindak secara cermat agar tidak menimbulkan kerugian pada masyarakat. 


\section{Res Nullius}

Law Journal

Vol. 2 No. 1 Januari 2020

Untuk melaksanakan azas tersebut Peraturan Pemerintah nomor 37 tahun 1998 tentang Peraturan Jabatan PPAT terdapat ketentuan yang memerintahkan PPAT menerapkan prinsip kehati-hatian dalam pelaksanaan tugas jabatannya yaitu dalam Pasal 22 Peraturan Jabatan PPAT menyatakan bahwa "Akta PPAT harus dibacakan/dijelaskan isinya kepada para pihak dengan dihadiri oleh sekurang-kurangnya 2 orang saksi sebelum ditandatangani seketika itu juga oleh para pihak, saksi-saksi dan PPAT."

Menurut (Hatta Isnaini Wahyu Utomo dan Hendry Dwicahyo Wanda , 2017 : 468), akta wajib dibacakan dan dijelaskan isinya oleh PPAT karena tidak semua penghadap yang datang kepada PPAT bisa membaca dan mudah memahami apa yang tertulis di dalam akta yang akan ditandatanganinya. Dengan kewajiban PPAT membacakan dan menjelaskan isi akta akan membuat para pihak lebih mudah untuk mengerti apa yang sedang dilakukannya dan diharapkan mampu memberikan rasa keadilan bagi semua pihak karena masing-masing hak dan kewajiban dari pihak dijelaskan oleh PPAT melalui pembacaan akta tersebut. Pembacaan akta oleh PPAT diharapkan membuat para penghadap lebih mengerti apa yang tertuang dalam akta yang akan ditandatanganinya dan mampu menghindari adanya gugatan dari salah satu pihak di kemudian hari akibat adanya perbedaan penafsiran terhadap hal-hal yang tertulis dalam akta.

Pasal 28 ayat (2) Peraturan Kepala BPN Nomor 1 tahun 2006 tentang Ketentuan Pelaksanaan Peraturan Pemerintah tentang Peraturan Jabatan PPAT menyebutkan : karena:

PPAT diberhentikan dengan tidak hormat dari jabatannya oleh Kepala Badan,

a. melakukan pelanggaran berat terhadap larangan atau kewajiban sebagai PPAT;

b. dijatuhi hukuman kurungan/penjara karena melakukan kejahatan perbuatan pidana yang diancam hukuman kurungan atau penjara paling lama 5 (lima) tahun atau lebih berat berdasarkan putusan pengadilan yang sudah mempunyai kekuatan hukum tetap;

c. melanggar kode etik profesi.

Pelanggaran berat sebagaimana dimaksud antara lain:

a. membantu melakukan permufakatan jahat yang mengakibatkan sengketa atau konflik pertanahan;

b. melakukan pembuatan akta sebagai permufakatan jahat yang mengakibatkan sengketa atau konflik pertanahan;

c. melakukan pembuatan akta di luar daerah kerjanya kecuali yang dimaksud dalam Pasal 4 dan Pasal 6 ayat (3);

d. memberikan keterangan yang tidak benar di dalam akta yang mengakibatkan sengketa atau konflik pertanahan;

e. membuka kantor cabang atau perwakilan atau bentuk lainnya yang terletak di luar dan atau di dalam daerah kerjanya sebagaimana dimaksud dalam Pasal 46;

f. melanggar sumpah jabatan sebagai PPAT;

g. pembuatan akta PPAT yang dilakukan, sedangkan diketahui oleh PPAT yang bersangkutan bahwa para pihak yang berwenang melakukan perbuatan hukum atau kuasanya sesuai peraturan perundang-undangan tidak hadir dihadapannya;

h. pembuatan akta mengenai hak atas tanah atau Hak Milik Atas Satuan Rumah Susun yang oleh PPAT yang bersangkutan diketahui masih dalam sengketa yang 
mengakibatkan penghadap yang bersangkutan tidak berhak melakukan untuk perbuatan hukum yang dibuktikan dengan akta;

i. PPAT tidak membacakan aktanya dihadapan para pihak maupun pihak yang belum atau tidak berwenang melakukan perbuatan sesuai akta yang dibuatnya;

j. PPAT membuat akta dihadapan para pihak yang tidak berwenang melakukan perbuatan hukum sesuai akta yang dibuatnya;

k. PPAT membuat akta dalam masa dikenakan sanksi pemberhentian sementara atau dalam keadaan cuti;

1. lain-lain yang ditetapkan oleh Kepala Badan.

Selain itu Keputusan Menteri Agraria dan Tata Ruang/ Kepala Badan Pertanahan Nasional Nomor 112/KEP-4.1/IV/2017 tentang Kode Etik PPAT dalam Pasal 6 ayat (1) menetapkan sanksi berupa :

a. Teguran;

b. Peringatan;

c. Schorsing (pemecatan sementara) dari keanggotaan IPPAT;

d. Onzetting (pemecatan) dari keanggotaan IPPAT;

e. Pemberhentian dengan tidak hormat dari keanggotaan IPPAT.

Penjatuhan sanksi disesuaikan dengan kuantitas dan kualitas pelanggaran yang dilakukan anggota tersebut.

Selanjutnya Menteri Agraria dan Tata Ruang/Kepala Badan Pertanahan telah mengeluarkan Peraturan Nomor 2 tahun 2018 tentang Pembinaan dan Pengawasan Pejabat Pembuat Akta Tanah yang bertujuan untuk mewujudkan PPAT yang profesional, berintegritas dan melaksanakan jabatan PPAT sesuai dengan ketentuan peraturan perundang-undangan dan Kode Etik.

Pembinaan dan pengawasan terhadap PPAT dilakukan oleh Menteri dan Pembinaan dan pengawasan di daerah dilakukan oleh Kepala Kantor Wilayah BPN dan Kepala Kantor Pertanahan.

Pembinaan oleh Menteri sebagaimana dimaksud dalam Pasal 4 ayat (1), dapat berupa:

a.penentuan kebijakan mengenai pelaksanaan tugas jabatan PPAT;

b. pemberian arahan pada semua pihak yang berkepentingan terkait dengan kebijakan di bidang ke-PPAT-an;

c. menjalankan tindakan yang dianggap perlu untuk memastikan pelayanan PPAT tetap

berjalan sesuai dengan ketentuan peraturan perundangundangan; dan/atau

d. memastikan PPAT menjalankan tugas dan fungsi sesuai dengan Kode Etik.

Pengawasan terhadap PPAT sebagaimana dimaksud dalam Pasal 4, dapat berupa:

a. pengawasan terhadap pelaksanaan jabatan PPAT; dan

b. penegakan aturan hukum sesuai dengan ketentuan peraturan perundang-undangan di bidang PPAT.

Adapun pemberian sanksi yang dikenakan terhadap PPAT yang melakukan pelanggaran dapat berupa:

a. teguran tertulis;

b.pemberhentian sementara;

c.pemberhentian dengan hormat; atau

d. pemberhentian dengan tidak hormat.

\section{KESIMPULAN}


Faktor penyebab sengketa tanah masih tetap berlangsung pada saat ini karena ketidaktersediaan akta otentik yang membuktikan kepemilikan hak tanah. Masyarakat belum menyadari pentingnya pendaftaran tanah, karena keterbatasan pengetahuan akan peraturan perundang-undangan, sehingga masih terdapat peralihan hak atas tanah yang dilakukan di bawah tangan tanpa melibatkan PPAT.Selanjutnya Peran PPAT sangat penting dalam pendaftaran tanah, karena produknya dijadikan dasar untuk penerbitan sertifikat tanah sebagai alat bukti kuat yang dapat meminimalisir sengketa tanah.

Untuk itu Pejabat Pembuat Akta Tanah dalam melaksanakan tugasnya agar selalu berhati-hati dan profesional guna menghindari kekeliruan yang dapat menyebabkan kerugian kepada masyarakat.

\section{DAFTAR PUSTAKA}

Abdul Manan , 2000, Penerapan Hukum Acara Perdata di Lingkungan Peradilan Agama, Yayasan Al Hikmah, Jakarta.
---------------- 2007 , Etika Hakim Dalam Ppenyelenggaraan Peradilan, Kencana ,Jakarta

Boedi Harsono, 2003, Hukum Agraria Indonesia, Sejarah Pembentukan Undang -

Undang Pokok Agraria, Isi dan Pelaksanaannya, Djambatan, Jakarta.

Darwin Ginting, 2011, Penyelesaian Sengketa Pertanahan di Indonesia, Seminar Tentang Penyelesaian Sengketa dan Konflik Pertanahan Dalam Perspektif Pembaharuan Hukum Pertanahan Nasional,Bandung. 17 Nopember.

Hatta Isnaini Wahyu Utomo dan Hendry Dwicahyo Wanda , 2017 , Jurnal Hukum Ius Quia Iustum No. 3 Vol. 24.

Makhfudz, 2013, Hukum Administrasi Negara,Graha Ilmu, Yogyakarta.

Nurhasan Ismail,2011, Arah Politik Hukum Pertanahan dan Perlindungan Kepemilikan Tanah Masyarakat, dalam Seminar Tentang Penyelesaian Sengketa dan Konflik Pertanahan Dalam Perspektif Pembaharuan Hukum Pertanahan Nasional,Bandung. 17 Nopember.

Ronny Hanitijo, 1988, Metode Penelitian Hukum dan Jurimetri, Ghalia, Indonesia, Jakarta.

Rosiana Hayanti, 2018, Sengketa Tanah Sepanjang Tahun 2018, Kompas, Rabu, 27/2/2019.

Sihombing, 2005 Evolusi Kebijakan Pertanahan Dalam Hukum Tanah Nasional, Gunung Agung, Jakarta.

Soerjono Soekanto dan Sri Mamudji, 1995. Penelitian Hukum Normatif, Raja Grafindo Persada,

Supriadi, 2008, Hukum Agraria, Sinar Grafika, Jakarta.

Waskito dan Hadi Arnowo, 2017, Pertanahan, Agraria dan Tata Ruang, Kencana, Jakarta.

Yahya Harahap , 2014, Hukum Acara Perdata, Tentang Gugatan, Persidangan, Pembuktian dan Putusan Pengadilan, Sinar Grafika, Jakarta..Yunus Wahid, 2014, Pengantar Hukum tata Ruang, , Kencana Prenadamedia Grup,Jakarta.

Undang-Undang Dasar Republik Indonesia 1945.

Undang-Undang Nomor 5 Tahun 1960 tentang Peraturan dasar Pokok-Pokok Agraria.

Peraturan Pemerintah Nomor 24 tahun 1997 tentang Pendaftaran Tanah.

Pemerintah Nomor 37 tahun 1998 tentang Peraturan Jabatan Pembuat Akta Tanah 
Vol. 2 No. 1 Januari 2020

Peraturan Pemerintah Nomor 24 tahun 2016 tentang Perubahan atas PP nomor 37 tentang Peraturan Jabatan Pembuat Akta Tanah.

Peraturan Kepala BPN Nomor 1 tahun 2006 tentang Ketentuan Pelaksanaan Peraturan Peraturan Pemerintah Republik Indonesia Nomor 37 Tahun 1998 Tentang Peraturan Jabatan Pejabat Pembuat Akta Tanah.

Peraturan Menteri Agraria dan Tata Ruang / Badan Pertanahan Nasional Nomor 11 Tahun 2016 tentang Penyelesaian Kasus Pertanahan.

Peraturan Menteri Agraria dan Tata Ruang/Kepala Badan Pertanahan Nomor 2 tahun 2018 tentang Pembinaan dan Pengawasan Pejabat Pembuat Akta Tanah 